\title{
Simple, Axial Ligand-Mediated Route to Water-Soluble Iridium Corroles
}

\author{
Ivar K. Thomassen, Daniel Rasmussen, Rune F. Einrem, and Abhik Ghosh*
}

Cite This: ACS Omega 2021, 6, 16683-16687

Read Online

ABSTRACT: The synthesis and purification of water-soluble porphyrin-type compounds for photodynamic therapy and other medical applications is often a tedious exercise. Here, we have investigated the simple stratagem of adding a water-soluble axial ligand to the standard protocol for iridium insertion into simple mesotriarylcorroles. Early results showed that six-coordinate $\operatorname{Ir}[\mathrm{T} p \mathrm{XPC}]$ $(\mathrm{dna})_{2}$ derivatives, in which $\mathrm{T} p \mathrm{XPC}=\operatorname{tris}($ para-X-phenyl $)$ corrole $(\mathrm{X}=$ $\mathrm{CF}_{3}, \mathrm{CN}, \mathrm{H}$, and $\mathrm{OMe}$ ) and $\mathrm{dna}=$ dinicotinic acid, are highly watersoluble. In the end, however, all axially nitrogen-ligated complexes proved unstable with respect to chromatographic purification and storage. Five-coordinate water-soluble phosphine adducts, fortunately, proved a great improvement. From the point of view of ease of

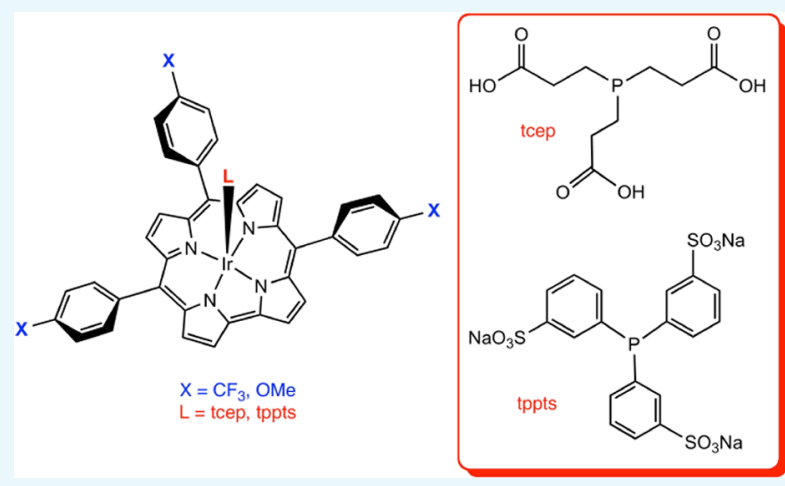
purification and storage, the best products proved to be $\operatorname{Ir}[\mathrm{TpXPC}](\mathrm{L})$, where $\mathrm{X}=\mathrm{CF}_{3}$ and $\mathrm{OMe}$ and $\mathrm{L}=$ tris(2-carboxyethyl)phosphine (tcep) and trisodium tris(3-sulfonatophenyl)phosphine (tppts); carefully optimized synthetic protocols are presented for these four compounds.

\section{INTRODUCTION}

Porphyrin-type compounds have long been a cornerstone of photodynamic therapy. ${ }^{1-5}$ Recently, porphyrin analogues such as corroles, 6,7 have also proved promising as anticancer compounds. ${ }^{8,9}$ Several families of $5 \mathrm{~d}$ metallocorroles (including $\mathrm{ReO},{ }^{10} \mathrm{OsN},{ }^{11} \mathrm{Ir}^{12}{ }^{\mathrm{Pt}},{ }^{13}$ and $\mathrm{Au}^{14-17}$ corroles) that we and others have studied in recent years are relevant in this connection. Although they were originally of interest primarily as curious, size-mismatched metal-ligand assemblies, their photophysical properties, especially near-infrared (NIR) phosphorescence under ambient conditions, now promise a wide range of practical applications, ${ }^{18,19}$ such as in oxygen sensors, photodynamic therapy, and dye-sensitized solar cells and for triplet-triplet annihilation upconversion. ${ }^{20-28} \mathrm{~A}$ number of these applications, especially in the biomedical sphere, require water-soluble derivatives of the complexes, which are typically accessible via cumbersome synthetic and purification steps. $^{2,29,30}$ A recent reinvestigation of iridium corroles (in which 4-picolinic acid derivatives were found to be partially water-soluble) suggested that the use of water-soluble axial ligands might afford a simple, one-pot route to watersoluble Ir corroles as a new class of singlet oxygen photosensitizers. ${ }^{31}$ The beguilingly simple exercise, however, threw up unexpected challenges. Many of the compounds synthesized proved unstable, decomposing upon chromatographic purification or storage. Here, we detail carefully optimized synthetic protocols for four complexes (Scheme 1) that could be readily purified and stored and are therefore suitable for further investigations of potential applications.

\section{RESULTS AND DISCUSSION}

Six different meso-tris(para-X-phenyl)corrole ligands, $\mathrm{H}_{3}[\mathrm{~T} p \mathrm{XPC}]\left(\mathrm{X}=\mathrm{NO}_{2}, \mathrm{CF}_{3}, \mathrm{CN}, \mathrm{H}, \mathrm{Me} \text {, and } \mathrm{OMe}\right)^{32-34}$ as well as meso-tris(pentafluorophenyl)corrole, $\mathrm{H}_{3}$ [TPFPC], ${ }^{35}$ were examined throughout as equatorial ligands. For axial ligands, we initially examined five nitrogen ligands-4-picolinic acid (4pa; Figure 1), 3,5-pyridinedicarboxylic acid (also known as dinicotinic acid, dna), nitrilotriacetic acid (nta), 5hydroxypyridine-3-carboxylic acid, and 4-pyridylboronic acid. Four different stationary phases were used for chromatographic purification of the complexes-silica gel, basic and neutral alumina, Florisil, and fully endcapped $\mathrm{C}_{18}$ reversed-phase silica gel. Although iridium insertion could be accomplished for all of the corroles except $\mathrm{X}=\mathrm{NO}_{2}$, the great majority of the complexes proved unstable; bright green solutions of the freshly prepared complexes frequently turned brown, often with the decomposition product sticking to the glass walls of the reaction vessel. The most promising of the lot proved to be the dna complexes $\operatorname{Ir}[\mathrm{T} p \mathrm{XPC}](\mathrm{dna})_{2}\left(\mathrm{X}=\mathrm{CF}_{3}, \mathrm{CN}, \mathrm{H}\right.$, and OMe; Figure 2), exhibiting high water solubility, but these too proved unstable upon chromatographic workup and/or

Received: May 7, 2021

Accepted: June 7, 2021

Published: June 15, 2021 
Scheme 1. Synthesis of Four Stable, Water-Soluble Iridium Corroles
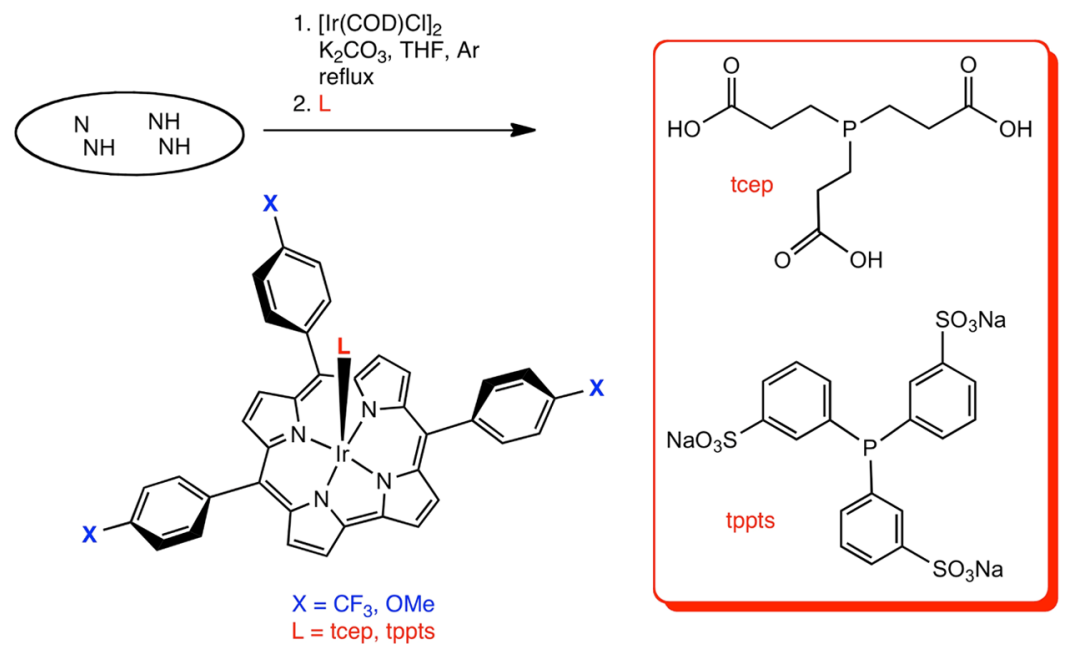

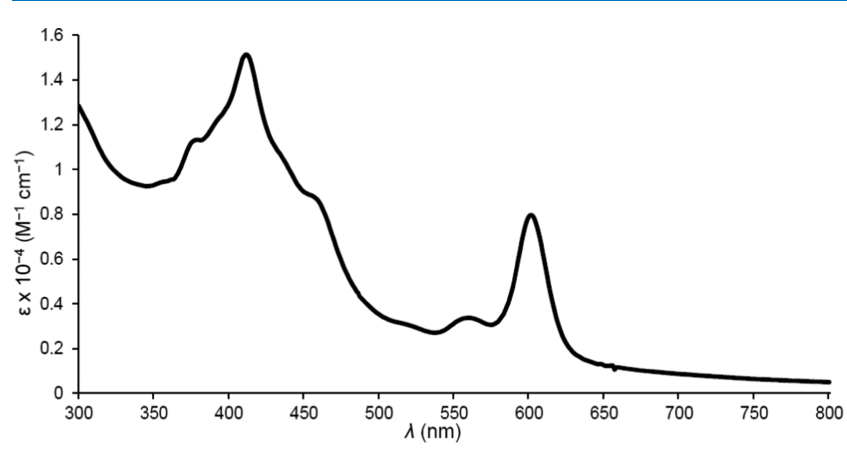

Figure 1. UV-vis spectrum of $\operatorname{Ir}[\mathrm{T} p \mathrm{OMePC}](4 \mathrm{pa})_{2}$ in methanol.

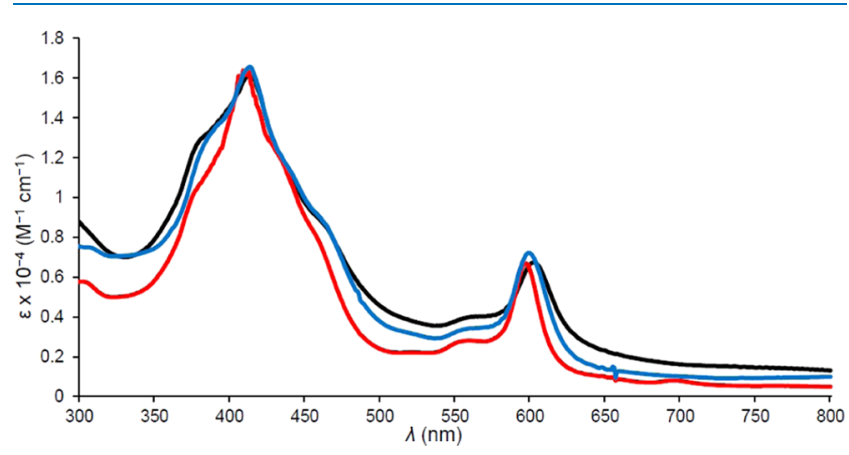

Figure 2. UV-vis comparison of freshly prepared $\operatorname{Ir}[\mathrm{T} p \mathrm{OMePC}]$ $(\text { dna })_{2}$ (black), $\operatorname{Ir}[\mathrm{TPC}](\mathrm{dna})_{2}$ (red), and $\operatorname{Ir}\left[\mathrm{T}^{2} \mathrm{CF}_{3} \mathrm{PC}\right](\mathrm{dna})_{2}$ (blue) in methanol.

storage, as indicated by the disappearance of the highly characteristic optical spectra. Attempts to avoid chromatography by resorting to solvent extraction and vacuum filtration ultimately also proved unsuccessful.

Mass spectrometric analyses of the decomposed complexes generally revealed large quantities of free axial ligands, suggesting that they tend to fall off during chromatographic purification. This observation led us to switch to water-soluble phosphine ligands, ${ }^{36}$ of which we examined three-tris(2carboxyethyl)phosphine (tcep), trisodium tris(3sulfonatophenyl)phosphine (tppts), and tris(hydroxymethyl)phosphine (thp). Like triphenylphosphine, ${ }^{37}$ these phosphine ligands also led to five-coordinate complexes, which fortunately also proved distinctly more stable than the nitrogen-ligated complexes described above. Of the phosphine complexes, the thp derivatives proved poorly soluble in water (presumably reflecting the lower hydrophilicity of the alcohol functionality relative to carboxylate and sulfonate) and were accordingly excluded from further examination in our study. Fortunately, the tcep and tppts complexes proved fully soluble in distilled water (see Figures 3-5 and Table 1 for representative optical

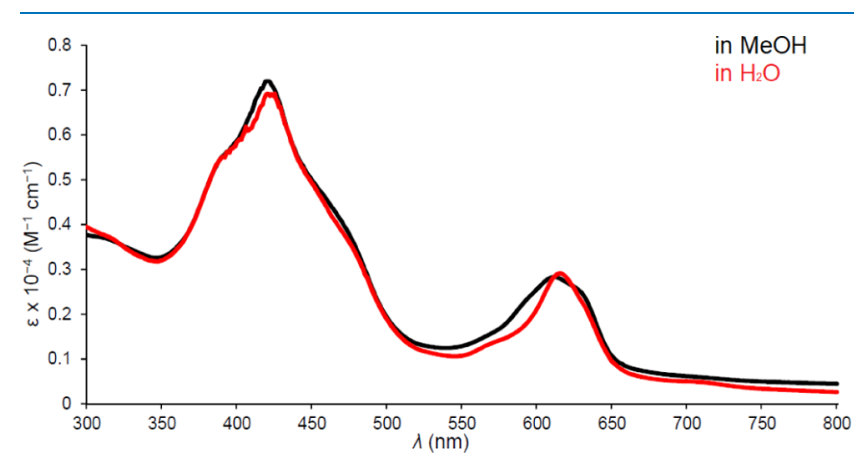

Figure 3. $\mathrm{UV}$-vis spectrum of $\operatorname{Ir}\left[\mathrm{T}_{\mathrm{CCF}} \mathrm{PC}\right]($ tcep) in methanol and water.

Table 1. Absorption Maxima $(\lambda, \mathbf{n m})$ for Ir Corroles ${ }^{a}$

\begin{tabular}{|c|c|c|c|}
\hline complex & solvent & $B$ & Q \\
\hline $\operatorname{Ir}[\mathrm{T} p \mathrm{OMePC}](\mathrm{tcep})$ & $\mathrm{MeOH}$ & $389,411^{*}$ & $609^{*}$ \\
\hline $\operatorname{Ir}[\mathrm{T} p \mathrm{OMePC}]$ (tppts) & $\mathrm{MeOH}$ & $391,413^{*}$ & $559,594^{*}$ \\
\hline 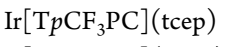 & $\mathrm{MeOH}$ & $420^{*}$ & $610^{*}$ \\
\hline $\operatorname{Ir}\left[\mathrm{T} p \mathrm{CF}_{3} \mathrm{PC}\right]$ (tppts) & $\mathrm{MeOH}$ & $413^{*}, 427$ & $556,594^{*}$ \\
\hline $\operatorname{Ir}[\mathrm{T} p \mathrm{OMePC}](\mathrm{tcep})$ & $\mathrm{H}_{2} \mathrm{O}$ & $416^{*}$ & $615^{*}$ \\
\hline 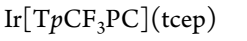 & $\mathrm{H}_{2} \mathrm{O}$ & $425^{*}$ & $615^{*}$ \\
\hline $\operatorname{Ir}\left[\mathrm{T} p \mathrm{CF}_{3} \mathrm{PC}\right](\mathrm{tppts})$ & $\mathrm{H}_{2} \mathrm{O}$ & $413^{*}$ & $557,595^{*}$ \\
\hline
\end{tabular}

${ }^{a}$ The numbers marked with an asterisk indicate the wavelengths with the most intense absorption.

spectra and spectral data). A number of tcep complexes (especially for $\mathrm{X}=\mathrm{CN}, \mathrm{H}$, and $\mathrm{Me}$ ), however, proved somewhat hygroscopic, and the optical spectra exhibited broadening upon prolonged standing in water. In contrast, $\operatorname{Ir}\left[\mathrm{T} p \mathrm{CF}_{3} \mathrm{PC}\right]$ (tcep) proved unusually rugged, remaining unchanged in air and both aqueous and nonaqueous solutions for days. Finally, the tppts complexes proved highly stable (albeit slightly hygroscopic, thereby thwarting our attempts at 
obtaining accurate elemental analyses) as well as readily purifiable via column chromatography on regular silica gel without any problems.

A brief word on the optical spectra of the new compounds may be of interest. The spectra (Figures 1-5) clearly show highly distinctive absorption profiles, including a complex Soret manifold and a $Q$ manifold, whose shape also varies considerably. Thus, the sharp and intense $Q$ band of $\operatorname{Ir}\left[\mathrm{T} p \mathrm{CF}_{3} \mathrm{PC}\right]$ (tppts) (Figure 4) may be distinguished from

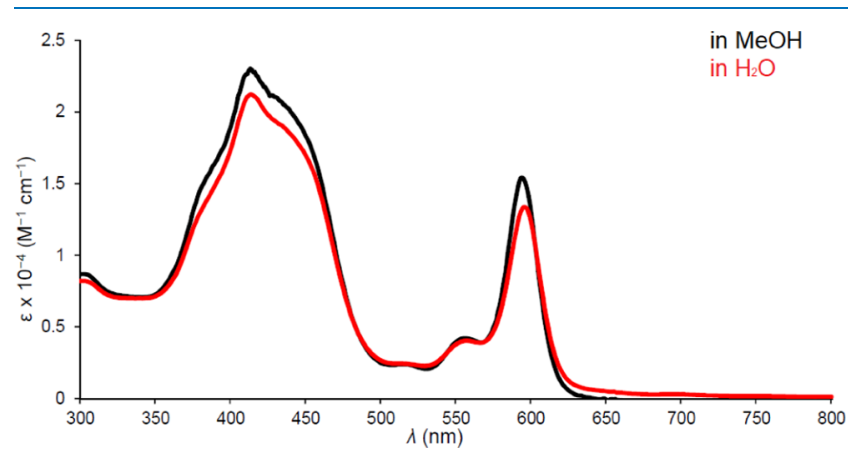

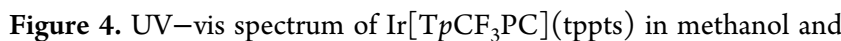
water.

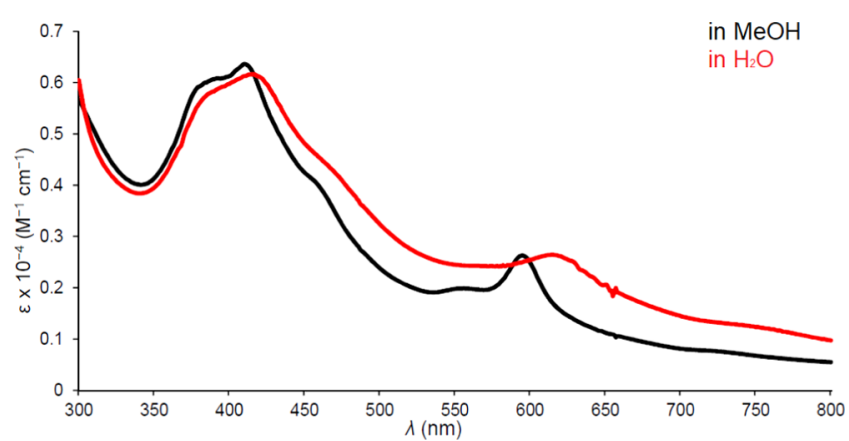

Figure 5. UV-vis spectrum of $\operatorname{Ir}[\mathrm{T} p \mathrm{OMePC}]$ (tcep) in methanol and water.

those of the tcep complexes (Figures 3 and 5). These distinctive spectra provided simple "spectroscopic handles" for assessing the integrity and purity of the compounds studied. A discussion of the electronic origin of the diverse absorption profiles, while of significant theoretical interest, is outside the scope of this study.

A couple of phosphine complexes exhibited a small quantity of impurity in their NMR spectra (see Figures S9-S16 in the Supporting Information); we have not identified this species as of yet but view a six-coordinate water or solvent adduct as a plausible candidate.

\section{CONCLUSIONS}

The present study was motivated by a desire to synthesize water-soluble iridium corroles for photodynamic therapy and other biomedical applications via the simple stratagem of employing a water-soluble axial ligand. Although ultimately successful, the exercise entailed unexpected challenges. Thus, the complexes with axial amine ligands such as 4-picolinic acid and dinicotinic acid proved unstable, decomposing over hours to days upon standing in water. Five-coordinate phosphine complexes, in contrast, proved much more stable and readily purifiable with reversed-phase column chromatography, with tcep and tppts emerging as the most promising axial ligands. Of the various complexes synthesized, $\operatorname{Ir}\left[\mathrm{TpCF}_{3} \mathrm{PC}\right]$ (tppts) is arguably the most attractive, considering its high water solubility, long-term stability in solution, and distinctive optical signature. The performance of the new compounds in photocytotoxicity measurements is currently under evaluation and will be reported in due course.

\section{EXPERIMENTAL SECTION}

Materials. Tris(2-carboxyethyl)phosphine hydrochloride (99\%), trisodium tris(3-sulfonatophenyl)phosphine $(<10 \%$ phosphine oxide), and tris(hydroxymethyl)phosphine (95\%) were purchased from Strem Chemicals, Inc. Free-base corroles were prepared as previously reported. ${ }^{33-35}$ Unless otherwise mentioned, all other chemicals were obtained from SigmaMillipore (Merck).

Instrumental Methods. UV-visible spectra were recorded on an HP 8453 spectrophotometer. ${ }^{1} \mathrm{H}$ NMR, ${ }^{19} \mathrm{~F}$ $\mathrm{NMR}$, and ${ }^{31} \mathrm{P}$ NMR spectra were recorded on a $400 \mathrm{MHz}$ Bruker Avance III HD spectrometer equipped with a $5 \mathrm{~mm}$ $\mathrm{BB} / 1 \mathrm{H}$ SmartProbe in $\mathrm{CD}_{3} \mathrm{OD}$ or $\left(\mathrm{CD}_{3}\right)_{2} \mathrm{SO}$. ${ }^{1} \mathrm{H} \mathrm{NMR}$ spectra were referenced to residual $\mathrm{CH}_{3} \mathrm{OH}(3.31 \mathrm{ppm})$ or to $\left(\mathrm{CH}_{3}\right)_{2} \mathrm{SO}(2.50 \mathrm{ppm})$. High-resolution electrospray-ionization (HR-ESI) mass spectra were recorded from methanolic solution on an LTQ Orbitrap XL spectrometer.

General Procedure for the Synthesis of $\operatorname{Ir}[\mathrm{T} p \mathrm{XPC}](\mathrm{L})$ ( $\mathrm{X}=\mathrm{OMe}, \mathrm{CF}_{3} ; \mathrm{L}=$ tcep, tppts). The iridium complexes were prepared according to a modified version of a previously reported procedure. ${ }^{12} \mathrm{Bis}(1,5$-cyclooctadiene $)$ diiridium(I) dichloride ( 1.5 equiv) and potassium carbonate (10 equiv) were dissolved in an anhydrous tetrahydrofuran (THF) solution (20 $\mathrm{mL})$ of a free-base corrole ( $\sim 0.025-0.1 \mathrm{mmol}, 1$ equiv). After degassing with argon for a few minutes, the solution was brought to reflux under an inert atmosphere. Heating was discontinued after $90 \mathrm{~min}$, and the phosphine (1 equiv) was added as a solution of anhydrous methanol $(10 \mathrm{~mL})$; the reaction mixture was then left to stir for $30 \mathrm{~min}$. As alluded to above, four products were purified and fully characterized, as described below. Because of the hygroscopic nature of the compounds, satisfactory elemental analyses, in general, could not be obtained; the yields accordingly should be regarded as upper limits.

Ir $[T p O M e P C]$ (tcep). The reaction mixture was rotaryevaporated to dryness. The dark solid residue was suspended in dichloromethane and thoroughly shaken; the solvent was decanted off to remove unreacted free-base corrole and other nonpolar impurities. This step was repeated with ethyl acetate and acetonitrile, finally leaving behind a dark green solid, which was dissolved in methanol. The solution was filtered to remove any remaining salts, and the filtrate was evaporated to dryness. The resulting solid was dissolved in a minimum amount of methanol and chromatographed on a fully $\mathrm{C}_{18^{-}}$ endcapped reversed-phase silica gel column with different $\mathrm{MeCN} / \mathrm{MeOH}$ mixed solvents as the mobile phase (as detailed below), yielding the expected product along with some silica particles as a light green solid. The silica particles were removed by suspending the solid in pentane, sonicating the suspension briefly, and filtering off the pentane solution containing the dissolved/micro-suspended silica. The dark green solid residue was dissolved in methanol and transferred to a new vessel; upon removal of the solvent under vacuum, 
the product was obtained as a deep green, hygroscopic solid. Yield $98 \mathrm{mg}(85 \%)$. UV-vis $\left(\mathrm{CH}_{3} \mathrm{OH}\right) \lambda_{\max }(\mathrm{nm})\left[\epsilon \times 10^{-4}\right.$ $\left.\left(\mathrm{M}^{-1} \mathrm{~cm}^{-1}\right)\right]: 389$ (sh, 0.56), $411(0.62), 609(0.25) .{ }^{1} \mathrm{H}$ NMR $\left(400 \mathrm{MHz}\right.$, methanol- $\left.d_{4}\right) \delta 8.63(\mathrm{~d}, J=4.0 \mathrm{~Hz}, 2 \mathrm{H}), 8.48(\mathrm{~d}, J$ $=4.0 \mathrm{~Hz}, 2 \mathrm{H}), 8.29(\mathrm{~d}, J=4.7 \mathrm{~Hz}, 2 \mathrm{H}), 8.09(\mathrm{t}, J=4.8 \mathrm{~Hz}$, $2 \mathrm{H}), 7.91-7.80(\mathrm{~m}, 4 \mathrm{H}), 7.32-7.14(\mathrm{~m}, 8 \mathrm{H}), 4.00(\mathrm{~d}, J=4.6$ $\mathrm{Hz}, 9 \mathrm{H}),-0.19(\mathrm{t}, J=8.2 \mathrm{~Hz}, 6 \mathrm{H}),-1.58(\mathrm{t}, J=8.2 \mathrm{~Hz}, 6 \mathrm{H})$. ${ }^{31} \mathrm{P}$ NMR (162 MHz, composite pulse-decoupled, methanol$\left.d_{4}\right) \delta-22.43$. MS (ESI): $\left[\mathrm{M}^{-}\right]=1055.2415$ (expt), 1055.2406 (calcd for $\operatorname{IrC}_{49} \mathrm{H}_{43} \mathrm{~N}_{4} \mathrm{O}_{9} \mathrm{P}$ ).

$\operatorname{Ir}[T p O M e P C]$ (tppts). The reaction mixture was rotaryevaporated to dryness, yielding a dark green solid. The residue was dissolved in a minimum amount of methanol and subjected to column chromatography (regular silica gel, 10:1 $\mathrm{MeCN} / \mathrm{MeOH}$, then $4: 1 \mathrm{MeCN} / \mathrm{MeOH}$ ) to obtain the title compound as a dichroic brown-green solid. Yield $16.6 \mathrm{mg}$ (22.5\%). UV-vis $\left(\mathrm{CH}_{3} \mathrm{OH}\right) \lambda_{\max }(\mathrm{nm})\left[\epsilon \times 10^{-4}\left(\mathrm{M}^{-1}\right.\right.$ $\left.\mathrm{cm}^{-1}\right)$ ]: 391 (sh, 1.82), 413 (2.02), 559 (sh, 0.72), 594 (0.84). ${ }^{1} \mathrm{H}$ NMR (400 MHz, DMSO-d 6 ) $\delta 7.94(\mathrm{~d}, J=1.8 \mathrm{~Hz}$, $4 \mathrm{H}), 7.83(\mathrm{dt}, J=7.6,1.5 \mathrm{~Hz}, 4 \mathrm{H}), 7.52(\mathrm{t}, J=7.6 \mathrm{~Hz}, 6 \mathrm{H})$, $7.48-7.43(\mathrm{~m}, 6 \mathrm{H}), 4.19-3.93(\mathrm{~m}, 9 \mathrm{H}), 3.38(\mathrm{t}, J=6.4 \mathrm{~Hz}$, $3 \mathrm{H}), 2.23(\mathrm{t}, J=7.4 \mathrm{~Hz}, 3 \mathrm{H}), 1.63(\mathrm{p}, J=6.9 \mathrm{~Hz}, 3 \mathrm{H}), 1.29-$ $1.17(\mathrm{~m}, 3 \mathrm{H}) .{ }^{31} \mathrm{P}$ NMR (162 MHz, composite pulsedecoupled, DMSO-d $\left.d_{6}\right) \delta$ 26.36. MS (ESI): $\left[\mathrm{M}^{-}\right]=$ 1328.1142 (expt), 1328.1154 (calcd for $\left.\mathrm{IrC}_{58} \mathrm{H}_{44} \mathrm{~N}_{4} \mathrm{O}_{12} \mathrm{~S}_{3} \mathrm{PNa}\right)$.

$\operatorname{Ir}\left[T p C F_{3} P C\right]$ (tcep). The purification was carried out as for $\operatorname{Ir}[\mathrm{T} p \mathrm{OMePC}]$ (tcep) to afford the title compound as a deep green, hygroscopic solid. Yield $26 \mathrm{mg}$ (90\%). UV-vis $\left(\mathrm{CH}_{3} \mathrm{OH}\right) \lambda_{\max }(\mathrm{nm})\left[\epsilon \times 10^{-4}\left(\mathrm{M}^{-1} \mathrm{~cm}^{-1}\right)\right]: 420(0.70)$, 610 (0.26). ${ }^{1} \mathrm{H}$ NMR (400 MHz, methanol- $\left.d_{4}\right) \delta 8.73(\mathrm{t}, J=$ $3.8 \mathrm{~Hz}, 2 \mathrm{H}), 8.62(\mathrm{~d}, J=7.9 \mathrm{~Hz}, 4 \mathrm{H}), 8.55(\mathrm{~d}, J=7.9 \mathrm{~Hz}, 2 \mathrm{H})$, $8.48(\mathrm{~d}, J=4.8 \mathrm{~Hz}, 2 \mathrm{H}), 8.33(\mathrm{dd}, J=4.8,1.5 \mathrm{~Hz}, 2 \mathrm{H}), 8.13-$ $8.11(\mathrm{~m}, 2 \mathrm{H}), 7.98(\mathrm{~d}, J=8.0 \mathrm{~Hz}, 4 \mathrm{H}), 7.94(\mathrm{~d}, J=8.0 \mathrm{~Hz}$, $2 \mathrm{H}),-0.28$ to $-0.33(\mathrm{~m}, 6 \mathrm{H}),-2.13(\mathrm{~s}, 6 \mathrm{H}) .{ }^{19} \mathrm{~F}$ NMR $(377$ $\mathrm{MHz}$, methanol- $\left.d_{4}\right) \delta-63.27 .{ }^{31} \mathrm{P}$ NMR $(162 \mathrm{MHz}$, composite pulse-decoupled, methanol- $\left.d_{4}\right) \delta-22.66$. MS (ESI): $\left[\mathrm{M}^{-}\right]=$ 1169.1697 (expt), 1169.1710 (calcd for $\operatorname{IrC}_{49} \mathrm{H}_{34} \mathrm{~N}_{4} \mathrm{~F}_{9} \mathrm{O}_{6} \mathrm{P}$ ).

$\operatorname{Ir}\left[T p C F_{3} P C\right]$ (tppts). The reaction mixture was rotaryevaporated to dryness, yielding a dark green solid. The residue was suspended in dichloromethane and shaken thoroughly, and the solvent was decanted off to remove unreacted free-base corrole and other less polar impurities. The solid residue was dissolved in a minimum amount of methanol and subjected to column chromatography (regular silica gel, 5:1 $\mathrm{CH}_{2} \mathrm{Cl}_{2} /$ $\mathrm{MeOH}$, then 1:1 $\mathrm{CH}_{2} \mathrm{Cl}_{2} / \mathrm{MeOH}$ ), affording the product as a dichroic red-green solid. Yield $26 \mathrm{mg}$ (52\%). UV-vis $\left(\mathrm{CH}_{3} \mathrm{OH}\right) \lambda_{\max }(\mathrm{nm})\left[\epsilon \times 10^{-4}\left(\mathrm{M}^{-1} \mathrm{~cm}^{-1}\right)\right]: 413$ (2.68), 427 (sh, 2.47), 556 (sh, 0.49), 594 (1.79). ${ }^{1} \mathrm{H}$ NMR (400 MHz, methanol- $\left.d_{4}\right) \delta 8.64(\mathrm{~d}, J=4.3 \mathrm{~Hz}, 2 \mathrm{H}), 8.43(\mathrm{~d}, J=4.8 \mathrm{~Hz}$, $2 \mathrm{H}), 8.16(\mathrm{~d}, J=4.8 \mathrm{~Hz}, 2 \mathrm{H}), 8.03-7.95(\mathrm{~m}, 4 \mathrm{H}), 7.90(\mathrm{~d}, J=$ $4.3 \mathrm{~Hz}, 2 \mathrm{H}), 7.88-7.51(\mathrm{~m}, 8 \mathrm{H}), 7.39-7.34(\mathrm{~m}, 3 \mathrm{H}), 6.76(\mathrm{t}$, $J=7.8 \mathrm{~Hz}, 3 \mathrm{H}), 5.33(\mathrm{~d}, J=1.8 \mathrm{~Hz}, 3 \mathrm{H}), 3.89(\mathrm{dd}, J=7.9,1.6$ $\mathrm{Hz}, 3 \mathrm{H}) .{ }^{19} \mathrm{~F}$ NMR (377 MHz, methanol- $\left.d_{4}\right) \delta-63.30 .{ }^{31} \mathrm{P}$ NMR (162 MHz, composite pulse-decoupled, methanol- $\left.d_{4}\right) \delta$ -25.59. MS (ESI): $\left[\mathrm{M}^{-}\right]=1421.0710$ (expt), 1421.0716 (calcd for $\mathrm{IrC}_{58} \mathrm{H}_{34} \mathrm{~N}_{4} \mathrm{~F}_{9} \mathrm{O}_{9} \mathrm{~S}_{3} \mathrm{P}$ ).

\section{ASSOCIATED CONTENT}

\section{SI Supporting Information}

The Supporting Information is available free of charge at https://pubs.acs.org/doi/10.1021/acsomega.1c02399.
UV-vis, HR-ESI mass, and ${ }^{1} \mathrm{H}$ NMR spectra (PDF)

\section{AUTHOR INFORMATION}

\section{Corresponding Author}

Abhik Ghosh - Department of Chemistry, UiT-The Arctic University of Norway, N-9037 Tromsø, Norway; 다이.org/0000-0003-1161-6364; Email: abhik.ghosh@ uit.no

\section{Authors}

Ivar K. Thomassen - Department of Chemistry, UiT-The Arctic University of Norway, N-9037 Tromsø, Norway; (1) orcid.org/0000-0001-7592-6260

Daniel Rasmussen - Department of Chemistry, UiT-The Arctic University of Norway, N-9037 Tromsø, Norway

Rune F. Einrem - Department of Chemistry, UiT-The Arctic University of Norway, N-9037 Tromsø, Norway

Complete contact information is available at:

https://pubs.acs.org/10.1021/acsomega.1c02399

\section{Author Contributions}

I.K.T. carried out the majority of the experimental work; D.R. and R.F.E. provided significant assistance. A.G. planned and coordinated the research. I.K.T. and A.G. together wrote the manuscript.

\section{Notes}

The authors declare no competing financial interest.

\section{ACKNOWLEDGMENTS}

This work was supported by the Research Council of Norway (grant no. 262229 to A.G.) and the Arctic Center for Sustainable Energy at UiT-The Arctic University of Norway.

\section{REFERENCES}

(1) Bonnett, R. Chemical Aspects of Photodynamic Therapy; CRC Press, 2000.

(2) Pandey, R. K.; Kessel, D.; Dougherty, T. J. Handbook of Photodynamic Therapy: Updates on Recent Applications of PorphyrinBased Compounds; World Scientific, 2016.

(3) Amos-Tautua, B. M.; Songca, S. P.; Oluwafemi, O. S. Application of porphyrins in antibacterial photodynamic therapy. Molecules 2019, 24, No. 2456

(4) Lin, Y.; Zhou, T.; Bai, R.; Xie, Y. Chemical approaches for the enhancement of porphyrin skeleton-based photodynamic therapy. $J$. Enzyme Inhib. Med. Chem. 2020, 35, 1080-1099.

(5) Tian, J.; Huang, B.; Nawaz, M. H.; Zhang, W. Recent advances of multi-dimensional porphyrin-based functional materials in photodynamic therapy. Coord. Chem. Rev. 2020, 420, No. 213410.

(6) Ghosh, A. Electronic Structure of Corrole Derivatives: Insights from Molecular Structures, Spectroscopy, Electrochemistry, and Quantum Chemical Calculations. Chem. Rev. 2017, 117, 3798-3881.

(7) Nardis, S.; Mandoj, F.; Stefanelli, M.; Paolesse, R. Metal complexes of corrole. Coord. Chem. Rev. 2019, 388, 360-405.

(8) Teo, R. D.; Hwang, J. Y.; Termini, J.; Gross, Z.; Gray, H. B. Fighting Cancer with Corroles. Chem. Rev. 2017, 117, 2711-2729.

(9) Jiang, X.; Liu, R.-X.; Hai-Yang, L.; Chang, C. K. Corrole-based photodynamic antitumor therapy. J. Chin. Chem. Soc. 2019, 66, 10901099.

(10) Einrem, R. F.; Gagnon, K. J.; Alemayehu, A. B.; Ghosh, A. Metal-Ligand Misfits: Facile Access to Rhenium-Oxo Corroles by Oxidative Metalation. Chem. - Eur. J. 2016, 22, 517-520.

(11) Alemayehu, A. B.; Gagnon, K. J.; Terner, J.; Ghosh, A. Oxidative Metalation as a Route to Size-Mismatched Macrocyclic Complexes: Osmium Corroles. Angew. Chem., Int. Ed. 2014, 53, 14411-14414. 
(12) Palmer, J. H.; Durrell, A. C.; Gross, Z.; Winkler, J. R.; Gray, H. B. Iridium Corroles. J. Am. Chem. Soc. 2008, 130, 7786-7787.

(13) Alemayehu, A. B.; Vazquez-Lima, H.; Beavers, C. M.; Gagnon, K. J.; Bendix, J.; Ghosh, A. Platinum Corroles. Chem. Commun. 2014, 50, 11093-11096.

(14) Alemayehu, A. B.; Ghosh, A. Gold Corroles. J. Porphyrins Phthalocyanines 2011, 15, 106-110.

(15) Rabinovich, E.; Goldberg, I.; Gross, Z. Gold(I) and Gold(III) Corroles. Chem. Eur. J. 2011, 17, 12294-12301.

(16) Thomas, K. E.; Alemayehu, A. B.; Conradie, J.; Beavers, C.; Ghosh, A. Synthesis and Molecular Structure of Gold Triarylcorroles. Inorg. Chem. 2011, 50, 12844-12851.

(17) Thomas, K. E.; Vazquez-Lima, H.; Fang, Y.; Song, Y.; Gagnon, K. J.; Beavers, C. M.; Kadish, K. M.; Ghosh, A. Ligand Noninnocence in Coinage Metal Corroles: A Silver Knife-Edge. Chem. - Eur. J. 2015, $21,16839-16847$.

(18) Mahammed, A.; Gross, Z. Corroles as triplet photosensitizers. Coord. Chem. Rev. 2019, 379, 121-132.

(19) Lemon, C. M. Corrole photochemistry. Pure Appl. Chem. 2019, 92, 1901-1919.

(20) Palmer, J. H.; Durrell, A. C.; Gross, Z.; Winkler, J. R.; Gray, H. B. Near-IR Phosphorescence of Iridium(III) Corroles at Ambient Temperature. J. Am. Chem. Soc. 2010, 132, 9230-9231.

(21) Sinha, W.; Ravotto, L.; Ceroni, P.; Kar, S. NIR-Emissive Iridium(III) Corrole Complexes as Efficient Singlet Oxygen Sensitizers. Dalton Trans. 2015, 44, 17767-17773.

(22) Alemayehu, A. B.; Day, J.; Mani, N. U.; Rudine, T.; Thomas, A. B.; Gederaas, K. E.; Vinogradov, O. A.; Wamser, S. A.; Ghosh, C. C.; Gold, A. Tris(carboxyphenyl)corroles as Multifunctional Materials: Room Temperature Near-IR Phosphorescence and Applications to Photodynamic Therapy and Dye-Sensitized Solar Cells. ACS Appl. Mater. Interfaces 2016, 8, 18935-18942.

(23) Borisov, S. M.; Alemayehu, A.; Ghosh, A. Osmium-Nitrido Corroles as NIR Indicators for Oxygen Sensors and Triplet Sensitizers for Organic Upconversion and Singlet Oxygen Generation. J. Mater. Chem. C 2016, 4, 5822-5828.

(24) Lemon, C. M.; Powers, D. C.; Brothers, P. J.; Nocera, D. G. Gold Corroles as Near-IR Phosphors for Oxygen Sensing. Inorg. Chem. 2017, 56, 10991-10997.

(25) Alemayehu, A. B.; McCormick, L. J.; Gagnon, K. J.; Borisov, S. M.; Ghosh, A. Stable Platinum(IV) Corroles: Synthesis, Molecular Structure, and Room-Temperature Near-IR Phosphorescence. ACS Omega 2018, 3, 9360-9368.

(26) Borisov, S. M.; Einrem, R. F.; Alemayehu, A. B.; Ghosh, A. Ambient-temperature near-IR phosphorescence and potential applications of rhenium-oxo corroles. Photochem. Photobiol. Sci. 2019, 18, $1166-1170$.

(27) Einrem, R. F.; Alemayehu, A. B.; Borisov, S. M.; Ghosh, A.; Gederaas, O. A. Amphiphilic Rhenium-Oxo Corroles as a New Class of Sensitizers for Photodynamic Therapy. ACS Omega 2020, 5, 10596-10601.

(28) Higashino, T.; Kurumisawa, Y.; Alemayehu, A. B.; Einrem, R. F.; Sahu, D.; Packwood, D.; Kato, K.; Yamakata, A.; Ghosh, A.; Imahori, H. Heavy Metal Effects on the Photovoltaic Properties of Metallocorroles in Dye-Sensitized Solar Cells. ACS Appl. Energy Mater. 2020, 3, 12460-12467.

(29) Singh, S.; Aggarwal, A.; Bhupathiraju, N. V. S. D. K.; Arianna, G.; Tiwari, K.; Drain, C. M. Glycosylated Porphyrins, Phthalocyanines, and Other Porphyrinoids for Diagnostics and Therapeutics. Chem. Rev. 2015, 115, 10261-10306.

(30) Luciano, M.; Brückner, C. Modifications of Porphyrins and Hydroporphyrins for Their Solubilization in Aqueous Media. Molecules 2017, 22, No. 980.

(31) Thomassen, I. K.; McCormick-McPherson, L. J.; Borisov, S. M.; Ghosh, A. Iridium Corroles Exhibit Weak Near-Infrared Phosphorescence but Efficiently Sensitize Singlet Oxygen Formation. Sci. Rep. 2020, 10, No. 7551.

(32) Wasbotten, I. H.; Wondimagegn, T.; Ghosh, A. Electronic Absorption, Resonance Raman, and Electrochemical Studies of Planar and Saddled Copper(III) Meso-Triarylcorroles. Highly SubstituentSensitive Soret Bands as a Distinctive Feature of High-Valent Transition Metal Corroles. J. Am. Chem. Soc. 2002, 124, 8104-8116.

(33) Gryko, D. T.; Koszarna, B. Refined methods for the synthesis of meso-substituted $\mathrm{A}_{3}$ - and trans- $\mathrm{A}_{2} \mathrm{~B}$-corroles. Org. Biomol. Chem. 2003, 1, 350-357.

(34) Koszarna, B.; Gryko, D. T. Efficient Synthesis of mesoSubstituted Corroles in a $\mathrm{H}_{2} \mathrm{O}-\mathrm{MeOH}$ Mixture. J. Org. Chem. 2006, 71, 3707-3717.

(35) Gross, Z.; Galili, N.; Saltsman, I. The First Direct Synthesis of Corroles from Pyrrole. Angew. Chem., Int. Ed. 1999, 38, 1427-1429.

(36) Pinault, N.; Bruce, D. W. Homogeneous catalysts based on water-soluble phosphines. Coord. Chem. Rev. 2003, 241, 1-25.

(37) Palmer, J. H.; Mahammed, A.; Lancaster, K. M.; Gross, Z.; Gray, H. B. Structures and Reactivity Patterns of Group 9 Metallocorroles. Inorg. Chem. 2009, 48, 9308-9315. 